\title{
VARIASI PEMAKAIAN BAHASA PADA MASYARAKAT TUTUR KOTA SINGARAJA
}

\author{
D. P. Ramendra \\ Jurusan Pendidikan Bahasa Inggris, Fakultas Bahasa dan Seni \\ Universitas Pendidikan Ganesha \\ Singaraja, Indonesia \\ e-mail:dewaramendra@yahoo.com
}

\begin{abstract}
Abstrak
Artikel ini bertujuan untuk (1) memerikan variasi pemakaian Bahasa pada masyarakat tutur Kota Singaraja dalam kaitannya dengan wangsa, pekerjaan dan umur, dan (2) menguraikan faktor-faktor yang mempengaruhi terjadinya variasi tersebut. Untuk mencapai tujuan tersebut, peneliti menerapkan pendekatan mixed method dengan melibatkan 120 subjek penelitian yang diperoleh melalui secara purposive dengan memperhatikan kriteria wangsa, pekerjaan dan umur. Data dikumpulkan melalui angket, wawancara dan perekaman. Hasil penelitian menunjukkan bahwa ada 3 variasi bahasa pada masyarakat tutur kota Singaraja yang terkait dengan tipe subjek. Pemakaian BA sebagai variasi dominan dipakai oleh tipe penutur TAD, TBD, TCD dan TCM. Mereka adalah kelompok penutur dari tri wangsa dari tipe pekerjaan yang bervariasi dan didominasi oleh umur tua. Sedangkan, variasi pemakaian BI didominasi oleh tipe subjek TAM, TBM, NAM dan NBM. Kelompok ini merupakan usia muda dari kelas sosial (pekerjaan) menengah ke atas, dan tri wangsa dan jaba. Terakhir, pemakaian BB didominasi oleh tipe subjek NAD,NBD, NCD dan NCM. Kelompok ini merupakan kelompok jaba dari tiga tipe pekerjaan dan didominasi oleh umur tua. Variasi pemakaian bahasa yang berbeda tersebut terkait erat dengan identitas yang ingin diproyeksikan oleh subjek (penutur).
\end{abstract}

Kata kunci: masyarakat tutur, pekerjaan, umur, variasi pemakaian bahasa dan wangsa.

\begin{abstract}
This article aimed at (1) describing the variation of language use in Singaraja speech community with regardto caste, type of jobs and age and (2) explaining the factors that influence such variation. To achieve those aims, the researcher applied mixed method research involving 120 subjects obtained through purposive samplings in consideration with the subjects' caste, jobs and age. The data were collected through questionairre, interview and recording. The results of the research showed that there were three variation of language use in Singaraja speech community in relation with the subjects' types. BA was dominantly used by subjects' type TAD, TBD, TCD and TCM. These subjects were from higher caste (tri wangsa) with all types of jobs and mostly at old age. BI was dominantly used by subjects' type TAM, TBM, NAM dan NBM. These subjects came from both higher and lower (jaba) caste, but they were all at young age and at the mid to high job category. BB was dominantly used by NAD,NBD, NCD dan NCM. These subjects were all from lower caste with various jobs' types and mostly at old age. These variation in language use were very closely related with the types of identity projected by the subjects (speakers).

Keywords: age, caste, job, language use variation and speech community.
\end{abstract}




\section{PENDAHULUAN}

Walaupun hampir setiap bahasa di dunia ini memiliki bentuk-bentuk tertentu (honorifiks) untuk mengungkapkan rasa hormat, tetapi tidak banyak yang memiliki bentuk sekompleks dan serumit kelima bahasa yang ada di Indonesia, yaitu: Bahasa Jawa, Bahasa Bali, Bahasa Madura, Bahasa Sunda dan Bahasa Sasak. Kekomplekan itu disebabkan karena ke-5 bahasa tersebut memiliki tingkatan-tingkatan yang berbeda atau secara umum sering disebut dengan Tingkat Tutur (TT).

Beberapa ahli (Wessing, 1974; Anderson, 1997 dan Karepun, 2007) menghipotesiskan bahwa TT pertama kali ditemukan pada budaya suku Jawa yang kemudian menyebar ke suku Sunda, suku Madura, suku Bali dan suku Sasak. TT memberikan pilihan bagi seorang penutur untuk berinteraksi dengan petutur terkait dengan hubungan status sosial penutur petutur. Secara normatif jika petutur memiliki status sosial yang lebih tinggi, maka penutur memakai TT yang lebih halus (sopan) untuk menunjukkan rasa hormat. Sedangkan, petutur bisa memilih TT lepas hormat. Dengan kata lain, TT merupakan penanda bagi perbedaan hierarki sosial antara penutur dan petutur.

Penentuan status sosial pada masyarakat tutur bahasa di Bali terbilang unik jika dibandingkan dengan masyarakat tutur lain. Hal ini terjadi karena selain posisi sosial, pekerjaan atau umur, masyarakat tutur Bahasa di Bali masih menempatkan wangsa sebagai elemen yang sangat dominan dalam penentuan status sosial. Menurut Suastra (1997), wangsa merupakan pengelompokan suatu masyarakat yang bersifat vertikal dan didasarkan atas 3 hal: (a) kelahiran, (b) kekuasaan raja dan (c) perkawinan. Wangsa itu sendiri dibagi atas 4 dengan urutan dari atas ke bawah, sbb: (a) brahmana, (b) ksatria, (c) wesia dan (d) jaba.

Ada ketidaksepakatan dalam pembagian TT diantara ahli bahasa (Shadeq, 2007). Hal ini bisa terjadi karena dasar klasifikasi TT adalah rasa. Walaupun demikian, perbedaan tersebut tidaklah terlalu penting terutama karena kesenjangan perbedaan klasifikasi tersebut tidak terlalu besar. Jendra, dkk (1975), misalnya, membagi TT menjadi kasar, madia dan alus. Bagus (1979) membagi TT menjadi kasar tak sopan, kasar sopan, madia, alus sor dan alus singgih. Narayana (1983) membagi tingkat tutur menjadi kasar pisan, kasar jabag, andap, madia, alus mider, alus sor dan alus singgih. Sedangkan, Kersten (1984) membagi TT menjadi bahasa biasa dan bentuk hormat.

TT sesungguhnya ditunjukkan dengan adanya pemakaian kata yang berbeda untuk mengungkapkan suatu ide yang sama terkait dengan hubungan status antara penutur - petutur. Dengan kata lain, TT bersifat alternasi leksikal. Misalnya:

- Ake lakar ngamah "Saya akan makan" (Basa Kasar)

- Cang lakar medaar "Saya akan makan" (Basa Biasa)

- Tiang pancang ngajeng "Saya akan makan" (Basa Alus)

Contoh tersebut jelas menunjukkan bahwa ada beberapa ekspresi berbeda untuk mengungkapkan satu pesan sama "Saya akan makan". Pesan yang sama tersebut diungkapkan dengan pemakaian kata (TT) yang berbeda dan TT tersebut menunjukkan bagaimana penutur - petutur terkait secara sosial.

Keberadaan TT ini pada masyarakat tutur Bahasa di Bali mengindikasikan adanya norma sopan santun berbahasa yang sangat ketat, sehingga seorang penutur perlu untuk tahu status petutur sebelum interaksi lebih lanjut. Sapaan yang sering dipakai untuk menanyakan status (wangsa) seseorang adalah Ampurayang, nawegang antuk linggih! "Mohon maaf, boleh saya tahu status anda!". Pertanyaan ini akan dijawab, misalnya, Nggih, tiang nak jaba! "Saya orang Jaba".

Pilihan varietas (bahasa) bagi penutur bahasa di Bali menjadi semakin beragam dengan keberadaan bahasa 
Indonesia (BI). BI merupakan bahasa resmi yang telah dikukuhkan menjadi bahasa nasional sejak kemerdekaan. Sebagai bahasa resmi, BI dijamin pemakaiannya oleh negara pada ranah-ranah resmi, seperti di kantor publik (pemerintahan), sekolah dll. Bahkan, banyak yang sudah menggungkapkan (Purwoko, 2008) bahwa $\mathrm{BI}$ juga telah memasuki ranah-ranah tak resmi, seperti keluarga dan tempat bermain (ketetanggaan)

Perbedaan yang paling mencolok antara $\mathrm{BI}$ dan BB adalah pada ketiadaan TT pada bahasa Indonesia. Hal ini mengindikasikan bahwa $\mathrm{BI}$ bersifat netral dan mengepankan persamaan. Sifat ini tentu saja sangat sesuai dengan nuansa masyarakat modern yang menghindari nuansa tradisional dan feodalisme yang menjadi ciri TT bahasa Bali. Hal ini mengakibatkan BI menjadi "satu-satunya bahasa komunikasi yang paling bergengsi" yang telah banyak menggeser fungsi-fungsi bahasa lokal (Purwoko, 2008)

Walaupun sudah ada beberapa penelitian yang dilakukan terkait dengan pemakaian Bahasa di Bali, tapi penelitian itu masih bersifat terbatas dan hanya dilakukan pada wilayah Bali selatan yang notabene merupakan wilayah yang "sangat kental dengan nuansa adat dan tradisi" (Karepun, 2007). Bagus (1979), misalnya, melakukan penelitian tentang pemakaian bahasa bali di wilayah Klungkung dan Denpasar. Sedangkan, Suastra (1988) melakukan penelitian yang sejenis di wilayah Denpasar. Berdasarkan pertimbangan ini, peneliti tertarik untuk melakukan penelitian tentang variasi pemakaian Bahasa pada masyarakat tutur Kota Singaraja.

Selain itu, masyarakat tutur Kota Singaraja memiliki karakteristik yang berbeda dengan masyarakat tutur Bahasa di Bali yang lain. Masyarakat tutur Kota Singaraja cenderung untuk mengabaikan keberadaan wangsa. Hal ini mungkin terkait dengan sejarah yang menceritakan bahwa Kota Singaraja (Buleleng) merupakan tempat berlindung dan bersembunyi bagi pelarian politik dari kerajaan-kerajaan di Bali Selatan dan ketika mereka di Singaraja mereka diminta untuk melepaskan status wangsa mereka untuk menjadi warga biasa (Sastrodiwiryo, 2011).

Sastrodiwiryo juga menjelaskan bahwa masyarakat tutur Kota Singaraja merupakan masyarakat tutur yang sangat terbuka dan mengedepankan solidaritas. Dari perspektif sejarah terlihat jelas bahwa masyarakat tutur tersebut sudah menerima beberapa kelompok yang beda budaya, beda etnis dan bahkan beda keyakinan dengan tangan terbuka. Misalnya, pada abad ke-8 sebelum munculnya kerajaan dan dinasti Warmadewa di Bali (abad ke-10) Jemaah-jemaah Budha Mahayana pertama telah menginjakkan kaki di pantai Bali Utara, yaitu di sekitar tempat yang sekarang dikenal dengan kawasan Lovina. Pada waktu itu orang-orang Bali Aga yang mendiami wilayah pegunungan Den Bukit menyambut jemaah budha ini dengan ramah. Bahkan, kalau diperhatikan sampai sekarang banyak orang dari berbagai latar belakang etnis yang berbeda tinggal menetap di Kota Singaraja.

Suryawan (2010) mengungkapkan bahwa kabupaten Buleleng terkenal sebagai 'bumi panas'. Wingarta (2009) yang mendukung opini tersebut menambahkan bahwa "kekasaran dan kekerasan watak orang-orang Buleleng itu juga sudah menjadi merek dan stereotipe bagi orangorang Buleleng yang mungkin identik dengan merek dan stereotipe yang diberikan kepada orang-orang dari etnis Madura dan atau Jawa Timur". Watak ini mungkin saja tercermin pada pemakaian bahasa pada masyarakat tutur Kota Singaraja, sehingga suatu kajian tentang pemakaian Bahasa di Bali pada masyarakat tutur Kota Singaraja menjadi sangat penting untuk dilakukan.

\section{LANDASAN TEORI}

Variasi Bahasa

Variasi bahasa bisa diartikan sebagai cara-cara yang berbeda untuk mengungkapkan sesuatu yang sama 
(Meyerhoff, 2011). Hal ini bisa terjadi, karena ketika seorang penutur menyatakan sesuatu melalui bahasa ia juga mengungkapkan siapa dirinya, dari masyarakat mana ia berasal, hubungannya dengan lawan tutur dan persepsinya tentang situasi tutur. Mesthrie (2009); dan Wardaugh (2006) sepakat dengan kata lain mengungkapkan variasi bahasa sebagai pola tutur berbeda yang terkait dengan situasi sosial dari suatu masyarakat tutur.

Variasi bahasa dimungkinkan, karena penutur suatu bahasa tertentu tidak hanya menguasai satu bahasa saja, tapi bisa beberapa bahasa atau satu bahasa beserta variasinya (khazanah verbal). Keberadaan khazanah verbal inilah yang memungkinkan seorang penutur untuk menggunakan cara-cara yang berbeda untuk mengungkapkan sesuatu melalui bahasa.

Wardaugh (2006) melabel
khazanah verbal sebagai kompetensi komunikasi dari seorang penutur yang menunjukan bukan hanya penguasaan akan suatu bahasa beserta variasinya, tetapi juga memahami norma-norma permakaiannya. Sehingga, kepemilikan akan khazanah verbal tidak hanya mengandung makna pasif, tapi aktif. Konsep kompetensi komunikasi itu tidak hanya berarti memiliki tapi juga mampu menggunakan secara baik dan tepat sesuai dengan tuntutan situasi, karena variasi itu umumnya bersifat fungsional dan spatial.

Hal yang paling penting dalam konsep variasi bahasa adalah kaitan antara bahasa dengan situasi sosial masyarakat tutur. Fishman (1972) membuat ilustrasi berikut untuk menjelaskan kaitan antara variasi bahasa dan masyarakat tutur. Variasi bahasa awalnya terkait erat dengan wilayah geografis yang disebut dengan dialek atau dialek geografis. Jika sekelompok besar imigran penutur daerah $A$ yang serba kurang secara ekonomi, kurang disukai di daerah yang didatangi dan tidak berpendidikan datang ke daerah penutur B, maka varasi (dialek) A tidak hanya bermakna sebagai asal usul (dialek geografis) bagi masyarakat tutur daerah $B$. Dialek A mewakili kelas sosial yang lebih rendah jika dibandingkan dengan dialek $B$. Dengan cara ini, variasi yang sebelumnya dilihat sebagai variasi regional berfungsi sebagai variasi sosial (sosiolek).

Jika penutur dari daerah A tidak diberi akses pada jejaring interaksi wilayah $B$, menikah hanya dengan sesamanya, terikat hanya dengan tradisi asli dan hanya menghargai pertemanan dengan sesamanya, maka mereka mungkin dilihat sebagai masyarakat tutur yang berbeda. Masyarakat tutur yang memiliki tujuan, kepercayaan dan tradisi yang berbeda. Pada gilirannya, variasi A tidak lagi dilihat sebagai variasi sosial, tetapi variasi etnis dan suatu saat bisa tumbuh menjadi bahasa yang berbeda.

Dalam masyarakat tutur A bisa juga ada penutur yang menguasai variasi $B$. Kecenderungannya adalah mereka menggunakan variasi $A$ untuk menciptakan keakraban dan solidaritas kelompok diantara mereka. Tapi, mereka menggunakan variasi $B$ untuk tujuan pekerjaan dan menunjukkan rasa hormat. Bagi penutur A, variasi A dan B merupakan variasi fungsional yang saling melengkapi dengan area yang terspesialisasi. Fungsi variasi $B$ yang dipakai oleh penutur $A$ tentu saja berbeda dengan fungsi variasi $B$ yang dipakai oleh penutur $B$ sendiri.

Sejalan dengan pernyataan Fishman, Chambers (2003) menjelaskan bahwa variasi bahasa tidaklah bersifat acak, tapi mengikuti suatu pola tertentu. Pola tersebut memiliki makna sosial yang menunjukkan kemunculan variasi linguistik yang sistematis (variabel tergantung) dalam hubungannya dengan struktur sosial (variabel bebas). Hubungan antara kedua variabel tersebut bersifat saling mempengaruhi dan tidak saling mendominasi, sehingga asumsi yang terbaik untuk menggambarkan hubungan kedua hal tersebut adalah korelasi. 


\begin{abstract}
Kalau diperhatikan secara mendalam faktor-faktor sosial yang mempengaruhi variasi linguistik antara satu setting dengan setting yang lainnya berbeda satu sama lain, atau memiliki skala berimbangan yang berbeda. Dalam $\mathrm{Hal}$ ini tidak masalah, karena setiap kajian adalah unik dan spesifik (Wardaugh, 2006). Meyerhoff (2011), misalnya, mengungkapkan bahwa variasi sosial yang bisa mengakibatkan variasi linguistik ialah umur, status sosial, jejaring sosial dan jender. Sedangkan, Chambers (2003) mengungkapkan bahwa variasi tersebut bisa disebabkan oleh kelas sosial, jejaring sosial, mobilitas sosial, umur dan jender.
\end{abstract}

\section{Faktor-Faktor Pemengaruh Pemilihan Bahasa}

Fasold (dalam Chaer dan Agustina, 2004) mengemukakan bahwa penelitian tentang pemilihan ragam bahasa bisa didasarkan pada tiga pendekatan: sosiologi, psikologi sosial dan antropologi. Fishman melalui pendekatan sosiologi menemukan adanya konteks institusional yang disebut domain sebagai penentu bagi pilihan-pilihan bahasa. Domain merupakan konstelasi faktor-faktor seperti lokasi, topik dan partisipan.

Lokasi merupakan tempat dimana suatu interaksi terjadi, itu bisa terjadi di rumah, di sekolah, di kantor pemerintahan atau ditempat ibadah. Topik terkait dengan apa yang dibahas atau dibicarakan dalam suatu interaksi. Topik yang dibicarakan bisa sangat luas, menyangkut berbagai hal/ isuisu yang terdapat dalam kehidupan di masyarakat. Topik bisa terkait dengan kehidupan di keluarga, pendidikan dan lain lain. Partisipan terkait dengan siapa berinteraksi dengan siapa. Hal ini terkait dengan identitas dari partisipan tersebut dan hubungan diantara mereka. Partisipan dari suatu interaksi bisa saja antara ayah-anak, kakak-adik, teman-teman dan lain lain.

Analisis domain ini kemudian terkait erat dengan formalitas, dimana ada domaindomain tertentu yang dianggap formal, ada yang tidak formal dan ada yang berada di antara formal-tidak formal. Pengelompokan domain berdasarkan formalitas ini pada gilirannya berimplikasi pada ragam bahasa untuk mmenuhi tuntutan domain itu sendiri. Adanya ragam formal, misalnya, digunakan untuk domain formal (mis. di sekolah, di pemerintahan dan lain lain) dan ragam tidak formal digunakan pada domain tidak formal (mis. di keluarga, pertemanan dan lain lain).

Berbeda dengan pendekatan sosial, psikologi sosial tidak mendekati pemilihan bahasa melalui struktur domain. Psikologi sosial mendekati masalah tersebut dengan meneliti proses psikologi manusia, yaitu apa yang memotivasi seorang penutur untuk memilih suatu ragam bahasa tertentu.

Mesthrie (2009) dan Spolsky (2003) mengemukakan bahwa alasan yang paling mendasar bagi timbulnya variasi bahasa terkait erat dengan jejaring sosial. Hal itu dinyatakan dengan 'people tend to talk like the people they talk to most of the time'. Pernyataan ini menunjukan bahwa seorang penutur cenderung untuk bertutur seperti orang yang paling sering diajak bertutur. Hal inilah yang dimaksud dengan ikatan sosial, suatu indikator psikologi yang sangat penting bagi seorang penutur untuk memilih atau menolak suatu ragam bahasa tertentu. Ikatan sosial ini sangat terkait dengan audience design. Audience design terkait dengan bagaimana seorang penutur mengatur (menyesuaikan) cara tuturnya dengan lawan tuturnya yang juga menunjukan bagaimana mereka terhubung satu sama lain.

Kedua ahli tersebut juga mengatakan bahwa terdapat suatu kecenderungan bagi para partisipan tutur untuk menggunakan pelafalan yang saling mendekati satu sama lain dalam suatu peristiwa tutur atau disebut dengan konvergen (accomodation). Fenomena ini menjelaskan bagaimana seorang penutur yang berpindah ke suatu tempat tertentu memodifikasi tuturnya sehingga sesuai dengan pola tutur baru di tempat tinggalnya yang baru tersebut. 
Hal sebaliknya bisa juga terjadi. Seorang penutur bisa juga menggunakan pelafalan atau cara tutur yang berbeda (menjauh) dari lawan tuturnya. Hal ini disebut dengan divergen. Divergen merupakan suatu fenomena dimana cara tutur seseorang menjauh dari cara tutur dengan siapa ia bertutur atau dari cara tutur dimana ia tinggal. Dalam hal ini, penutur tersebut menekankan pada fitur-fitur tuturan tertentu yang membedakannya dengan lawan tutur atau dengan cara tutur dimana ia tinggal. Dengan kata lain, ia lebih menghargai atau menunjukan kesetiaannya pada suatu kelompok lain yang tidak hadir.

\section{Tingkat Tutur Bahasa Bali}

Tingkat tutur, seperti tercermin dalam kata itu sendiri, ialah bentuk tutur yang bertingkat dari halus (sopan) sampai kasar terkait dengan tingkat penghormatan yang diberikan oleh seorang peserta tutur terhadap peserta tutur yang lainnya. Tingkat tutur dalam bahasa Bali sesungguhnya sekali ditunjukkan oleh pemakaian kosakata yang berbeda (alternasi leksikal) untuk suatu makna kata (kruna) yang sama. Untuk kata yang bermakna mati, misalnya, dipakai kata 'bangka' untuk kruna kasar, 'mati' untuk kruna andap, 'padem' untuk kruna alus sor, dan 'seda' untuk kruna alus singgih.

Dari segi rasa kata (kruna), bahasa Bali memiliki tujuh tingkat, yaitu 1) kruna alus mider, 2) kruna alus madia, 3) kruna alus singgih, 4) kruna alus sor, 5) kruna mider, 6) kruna andap dan 7) kruna kasar. Dari segi kalimat (lengkara), bahasa Bali memiliki lima tingkat, yaitu 1) lengkara alus singgih, 2) lengkara alus madia, 3) lengkara alus sor, 4) lengkara andap dan 5) lengkara kasar. Dari segi rasa bahasa, bahasa Bali memiliki empat tingkat, yaitu 1) alus, 2) madia, 3) andap dan 4) kasar (Dinas Kebudayaan Bahasa Bali Propinsi Bali, 2002).

Selanjutnya, Dinas Kebudayaan Bahasa Bali Propinsi Bali (2002) juga mengungkapkan bahwa dasar pembagian tingkat tutur adalah rasa bahasa. Itulah mengapa ada beberapa pandangan berbeda mengenai pembagian tingkat tutur. Suatra (1998) merumuskan perbedaan pandangan tersebut pada tabel 1 sebagai berikut.

Tabel 1 Tingkat Tutur B aha sa B ali Menurut Beberapa Ahliyang Berbeda




Walaupun ada beberapa pengelompokan TT yang cukup mendetail seperti terlihat pada tabel 1, tapi pada artikel ini TT bahasa Bali hanya dibagi menjadi tiga, yaitu basa alus (BA), basa biasa (BB) dan basa kasar (BK). BA merupakan basa yang dibangun oleh kruna alus mider, kruna alus madia, kruna alus singgih, kruna alus sor, kruna mider; sedangkan BB merupakan basa yang dibangun oleh kruna andap; sedangkan BK merupakan basa yang dibangun oleh kruna andap dan kruna kasar.

\section{MASALAH}

Terkait dengan paparan diatas, masalah yang dikaji pada artikel ini ada dua yaitu:

(1) Bagaimanakah variasi pemakaian Bahasa pada masyarakat tutur Kota Singaraja dalam kaitannya dengan wangsa, pekerjaan dan umur?

(2) faktor -faktor apakah yang mempengaruhi terjadinya variasi tersebut?

\section{TUJUAN}

Sejalan dengan masalah yang dirumuskan, maka tujuan dari penelitian ini adalah (1) untuk memerikan variasi pemakaian bahasa di Bali pada masyarakat tutur kota Singaraja dan (2) menguraikan faktor-faktor yang mempengaruhi terjadinya variasi tersebut

\section{METODE PENELITIAN}

Pendekatan yang dipakai dalam penelitian adalah pendekatan mixed method. Pendekatan ini dipilih karena pertanyaan yang diajukan pada rumusan masalah lebih tepat jika didekati dengan mixed method. Rumusan masalah ke-1 yang menanyakan tentang variasi pemakaian bahasa dijawab dengan memakai data angket (kuantitatif) dan data wawancara (kualitatif), sedangkan, jawaban atas rumusan ke-2 didekati melalui wawancara dan rekaman tuturan verbal. Selain itu, cara penarikan kesimpulan dilakukan adalah dengan cara induktif-deduktif yang merupakan ciri khas mixed method (Teddlie dan Tashakkori, 2009).

\section{SUBJEK PENELITIAN}

subjek penelitian adalah 120 orang yang dipilih secara purposive dengan kriteria sbb.

(a) Penduduk asli kota Singaraja

(b) Beretnis Bali

(c) Beragama Hindu

(d) Berumur minimal 20 tahun

(e) Sehat jasmani dan rohani

(f) Bersedia untuk dijadikan subjek penelitian

Selain itu, subjek penelitian tersebut dipilih juga berdasarkan kriteria wangsa, pekerjaan, dan umur. Hal ini dilakukan, karena variabel penelitian ini adalah wangsa, pekerjaan dan umur. Untuk lebih jelasnya, lihat tabel 2 .

\section{Tabel 2. Subjek Penelitian}

\begin{tabular}{|c|c|c|c|c|}
\hline \multirow{2}{*}{ Variabel } & \multicolumn{2}{|c|}{ T } & \multicolumn{2}{|c|}{ N } \\
\cline { 2 - 5 } & $\mathbf{D}$ & $\mathbf{M}$ & $\mathbf{D}$ & $\mathbf{M}$ \\
\hline A & 10 & 10 & 10 & 10 \\
\hline B & 10 & 10 & 10 & 10 \\
\hline C & 10 & 10 & 10 & 10 \\
\hline
\end{tabular}

Keterangan:
$A=$ posisi tinggi pada sektor pemerintahan dan swasta, seperti manajer, wakil manajer, kepala bagian, kepala biro, dekan, rektor
$\mathrm{T}=$ tri wangsa
$\mathrm{N}=$ non tri wangsa
$\mathrm{D}=$ umur $\geq 40$
$\mathrm{B}=$ posisi biasa (menengah) pada sektor swasta dan pemerintahan, seperti pemilik toko, pegawai hotel, staf PNS biasa, guru, dll. 
$\mathrm{C}=$ tenaga kurang terampil, seperti petani, buruh, penjaga malam, setengah pengangguran dan pengangguran

Selain subjek tersebut, satu orang dari setiap kelompok subjek (sel) diminta kesediaannya untuk direkam dan diwawancara. Perekaman dilakukan pada latar alamiah ketika subjek bertuturan dengan petutur alamiahnya (yang kebetulan ditemui) di empat ranah yang berbeda (keluarga, ketetanggaan (tempat bermain), tempat kerja, di luar tempat (jam) kerja. Setelah itu, subjek yang direkam tersebut diwawancarai dengan menerapkan pedoman wawancara yang sudah disiapkan.

\section{OBJEK PENELITIAN}

Objek penelitian ini meliputi perilaku bahasa dan tuturan verbal dari masyarakat tutur kota Singaraja.

\section{PENGUMPULAN DATA}

\section{Instrumen Pengumpulan Data}

Instrumen yang akan dipakai dalam mengumpulkan data ada 3: angket, alat perekam dan panduan wawancara. Angket yang disusun terdiri atas sejumlah pertanyaan yang dipakai untuk menggali data terkait dengan perilaku berbahasa masyarakat tutur Kota Singaraja. Pertanyaan tersebut terkait dengan bahasa yang umumnya dipakai responden ketika berinteraksi dengan petutur yang memiliki status sosial tertentu .

Alat perekam dipakai untuk merekam tuturan verbal subjek penelitian selama mereka bertutur dengan partisipan yang lainnya. Karena teknik pengumpulan data yang dipakai adalah observasi partisipasi, maka peneliti akan mengikuti, merekam dan bahkan juga berinteraksi dengan subjek penelitian. Melalui cara ini, data yang diharapkan didapatkan bersifat sealamiah mungkin.

Pedoman wawancara dipakai ketika peneliti mewawancara subjek penelitian. Pedoman wawancara yang digunakan terdiri atas beberapa pertanyaan yang dipakai untuk mengumpulkan data terkait dengan pilihan bahasa yang dipakai oleh subjek penelitian. Pedoman wawancara juga digunakan untuk mencari jawaban kenapa bahasa (tingkat) tutur tertentu lebih dipilih dibandingkan dengan bahasa (tingkat) tutur yang lainnya.

\section{Prosedur Pengumpulan Data}

Sebelum data dikumpulkan, subjek penelitian terlebih dahulu ditentukan. Setelah subjeknya dipilih, peneliti meminta kesediaan mereka untuk berpartisipasi dalam penelitian. Ke-120 subjek diminta untuk mengisi lembar angket dengan sejujur-jujurnya.

Setelah itu, satu subjek dari setiap kelompok diminta kesediannya untuk direkam. Setelah subjek setuju untuk direkam, peneliti menyertai subjek selama beberapa waktu untuk merekam tuturan verbal mereka dengan orang-orang di sekitar mereka. Proses perekaman dilakukan di empat ranah: keluarga, ketetanggaan (tempat bermain), tempat kerja dan di luar tempat (jam) kerja.

Setelah proses perekaman selesai, peneliti mewawancara subjek tersebut dan mengajukan berbagai pertanyaan terkait dengan temuan rekaman. Pertanyaan tersebut adalah pertanyaan tentang pemilihan variasi/ bahasa yang dipakai dalam hubungannya dengan siapa yang diajak bertuturan dan ranah pemakaian bahasa.

\section{ANALISIS DATA}

Karena data yang akan didapatkan adalah dalam bentuk kuantitatif dan kualitatif, maka prosedur analisis data dibagi menjadi 2. Secara kuantitatif, data yang diperoleh melalui angket akan dijumlahkan dan ditabulasikan. Kemudian, hasil tabulasi tersebut dipresentasekan untuk melihat keterkaitan secara umum antara pemakaian bahasa (TT) dengan wangsa, pekerjaan dan umur. 
Prosedur analisis data secara kualitatif meliputi 5 langkah: persiapan data, eksplorasi data, analisis data, representasi analisis data dan validasi data. Pada tahap persiapan data, data-data telah dikumpulkan melalui observasi partisipasi dan wawancara disiapkan, ditata dan ditranskripsi melalui pengetikan komputer. Hal ini dilakukan untuk memudahkan melakukan pengecekan kesesuaian antara data tutur dan transkripsinya.

\section{HASIL DAN PEMBAHASAN}

Pada bagian hasil dan pembahasan berikut dua sub pokok bahasan dibahas, yaitu Variasi Pemakaian Bahasa pada Masyarakat Tutur Kota Singaraja dalam kaitannya dengan Wangsa, Pekerjaan dan Umur dan faktor-faktor yang mempengaruhi variasi tersebut.

\section{Variasi Pemakaian Bahasa pada Masyarakat Tutur Kota Singaraja dalam kaitannya dengan Wangsa, Pekerjaan dan Umur}

Temuan yang diperoleh melalui angket yang secara umum bisa diringkas pada tabel 3 sebagai berikut.

Tabel 3. Rerata Prosentase Pemakaian Bahasa

\begin{tabular}{|c|c|c|c|c|c|}
\hline \multirow{2}{*}{ Kelompok subjek } & \multicolumn{5}{|c|}{ Prosentase Rerata } \\
\cline { 2 - 6 } & BA & BB & BK & BI & BL \\
\hline TAD & 62 & 8 & 0 & 30 & 0 \\
\hline TAM & 40 & 2 & 0 & 58 & 0 \\
\hline TBD & 59 & 11 & 0 & 30 & 0 \\
\hline TBM & 44 & 5 & 0 & 51 & 0 \\
\hline TCD & 67 & 22 & 0 & 11 & 0 \\
\hline TCM & 49 & 13 & 0 & 38 & 0 \\
\hline NAD & 12 & 45 & 0 & 43 & 0 \\
\hline NAM & 12 & 37 & 0 & 51 & 0 \\
\hline NBD & 18 & 55 & 0 & 27 & 0 \\
\hline NBM & 12 & 40 & 0 & 48 & 0 \\
\hline NCD & 15 & 70 & 0 & 15 & 0 \\
\hline NCM & 20 & 57 & 0 & 23 & 0 \\
\hline
\end{tabular}

Tabel 3 menunjukkan bahwa pada TAD pemakaian BA mencapai rerata $62 \%$, BB $8 \%$ dan BI $30 \%$; pada TAM pemakaian BA mencapai rerata $40 \% \mathrm{BB}, 2 \%$ dan $\mathrm{BI}$ $58 \%$; pada TBD pemakaian BA mencapai rerata $59 \%$, $\mathrm{BB} 11 \%$ dan $\mathrm{BI} 30 \%$; pada TBM pemakaian BA mencapai rerata $44 \%$, BB 5\% dan BI 51\%; pada TCD pemakaian BA mencapai rerata $67 \%$ BB, $22 \%$ dan Bl11\%; pada TCM pemakaian BA mencapai rerata $49 \%$, BB $13 \%$ dan BI $38 \%$; pada NAD pemakaian $\mathrm{BA}$ mencapai rerata $12 \%$, BB
45\% dan BI 43\%; pada NAM pemakaian BA mencapai rerata $12 \%$, BB $37 \%$ dan BI $51 \%$; pada NBD pemakaian BA mencapai rerata $18 \%$, BB $55 \%$ dan $\mathrm{BI} 27 \%$; pada NBM pemakaian $\mathrm{BA}$ mencapai rerata $12 \%$, $\mathrm{BB}$ $40 \%$ dan BI $48 \%$; pada NCD pemakaian BA mencapai rerata $15 \%$, BB $70 \%$ dan $\mathrm{BI} 15 \%$; dan pada NCM pemakaian BA mencapai rerata $20 \%$; $\mathrm{BB} 57 \%$ dan $\mathrm{BI} 23 \%$.

Untuk lebih jelasnya data pada tabel 2 divisualkan pada bagan 1 berikut. 




Bagan 1. Perbandingan pilihan bahasa antarkelompok Subjek

Bagan 1 memperlihatkan kecenderungan pemakaian variasi yang berbeda antarkelompok subjek. Pada TAD, TBD, TCD dan TCM terlihat bahwa BA merupakan pilihan bahasa yang paling umum dipakai yang diikuti oleh $\mathrm{BI}$ dan kemudian BB. Pemakaian BA kelihatan sangat menonjol pada ranah keluarga dan ketetanggaan; sementara pada ranah pekerjaan dan di luar tempat (jam) kerja, pemakaian BI pada TAD dan TCD hanya sedikit berada diatas pemakaian BA. Tetapi pada TCD dan TCM pemakaian BA lebih umum dibandingkan dengan $\mathrm{BI}$ di tempat(dan di luar) kerja.

Bagan tersebut juga menunjukkan bahwa pemakaian $\mathrm{BI}$ lebih umum dipakai oleh TAM dan TBM yang diikuti oleh BA dan kemudian BB. Pemakaian BA lebih tinggi dari BI pada ranah keluarga dan ketetanggaan; akan tetapi perbedaan yang sangat mencolok terlihat jelas pada ranah tempat kerja dan di luar tempat (jam) kerja yang mana pemakaian $B I$ sangat tinggi jika dibandingkan dengan BA.

Kecenderungan yang berbeda juga terlihat pada NAD,NBD, NCD dan NCM yang mana bahasa yang paling umum dipakai oleh kelompok tersebut adalah BB yang diikuti oleh $\mathrm{BI}$ dan $\mathrm{BA}$. Pada ranah keluarga dan ketetanggaan, BB terlihat sangat mendominasi; sedangkan pada ranah di tempat kerja dan di luar tempat (jam) kerja BB juga terlihat cukup mendominasi.

Pada NAM dan NBM terlihat bahwa bahasa yang paling umum dipakai adalah bahasa Indonesia yang diikuti oleh BB dan BA. Pada kedua tipe subjek ini, BB hanya mendominasi pada ranah keluarga saja, sementara $\mathrm{BI}$ mendominasi dengan sangat mencolok pada ranah-ranah lainnya.

\section{Faktor-Faktor Pemengaruh Variasi Pemakaian Bahasa pada Masyarakat Tutur Kota Singaraja}

Faktor identitas dan pelestarian identitas yang ditonjolkan cenderung untuk menjadi alasan utama bagi pemakaian variasi tertentu. BA terutama sekali dipakai untuk menunjukkan ke- tri wangsa -an oleh subjek dari tri wangsa. BA merupakan bahasa alus yang berasosiasi dengan kesopanan, kehalusan dan tradisi yang tentu saja terkait erat dengan tri wangsa dan umur, seperti terbetik diatas bahwa BA didominasi pemakaiannya oleh tipe subjek tri wangsa dan umur tua.

Sesungguhnya norma umum pemakaian BA di Bali ialah BA dipakai oleh orang yang berwangsa lebih rendah ke lebih tinggi (Gautama, 2006), akan tetapi norma tersebut sepertinya tidak sepenuhnya berlaku di masyarakat tutur di Singaraja. 
Hasil wawancara menunjukkan bahwa jika seseorang, walaupun tri wangsa dan lebih tua, memakai BB ketika berinteraksi, maka ia cenderung akan menerima BB juga dari lawan tuturnya, walaupun lawan tuturnya jaba dan lebih muda. Jadi, ketika dua orang bertemu, mereka perlu untuk bertransaksi terlebih dahulu tentang bahasa apa yang akan dipakai. Umumnya BA akan direspon BA, BB akan direspon BB dan BK akan direspon BK. Fenomena inilah yang disebut sebagai konvergensi oleh Bell (1984) yang mana dua partisipan tutur memiliki kecenderungan untuk saling "mendekat" satu sama lain melalui pemakaian gaya tutur yang sama.

Pemakaian $\mathrm{BI}$ didominasi oleh tipe subjek TAM, TBM, NAM dan NBM, karena $\mathrm{BI}$ bersifat netral, selain juga untuk menunjukkan nasionalisme. Ketika seseorang memakai $\mathrm{BI}$, ia tidak perlu lagi untuk menimbang-nimbang apakah harus memakai BA, BB atau BK dan akibat dari pemakaian dari variasi tersebut. BI bersifat praktis (netral), merupakan bahasa umum di Indonesia dan formal, sifat-sifat ini sangat cocok dengan tipe subjek usia muda baik itu yang memiliki pekerjaan $A$ ataupun $B$ (kelas menengah ke atas) yang kebanyakan bekerja di kantor pemerintahan ataupun di tempat lain yang termasuk di bidang pelayanan.

Pemakaian BB didominasi oleh tipe subjek NAD, NBD, NCD dan NCM. BB sering diungkapkan sebagai bahasa pergaulan di Singaraja dan kalau diperhatikan tipe subjek ini mendominasi penduduk kota Singaraja (Penduduk kota Singaraja dari tri wangsa sangatlah sedikit), sehingga wajar muncul ungkapan tersebut. BB merupakan variasi yang mengedepankan persamaan dan solidaritas yang sesuai dengan watak masyarakat Buleleng. Selain itu, variasi ini juga secara normatif adalah variasi yang dipakai diantara sesama jaba, walaupun di Singaraja BB juga sering dipakai oleh seorang jaba untuk menyapa seorang tri wangsa.

\section{SIMPULAN DAN SARAN SIMPULAN}

Berdasarkan atas temuan dan pembahasan maka dapat disimpulkan bahwa ada tiga variasi pemakaian varietas (bahasa) pada masyarakat tutur kota Singaraja yang terkait dengan tipe subjek. BA cenderung merupakan variasi dominan yang dipakai oleh subjek TAD, TBD, TCD dan TCM, yang merupakan kelompok penutur tri wangsa dari ketiga tipe pekerjaan dan didominasi oleh umur tua. Sedangkan, BI merupakan variasi dominan bagi subjek TAM, TBM, NAM dan NBM yang merupakan Kelompok kelompok usia muda dari kelas sosial (pekerjaan) menengah ke atas. Terakhir, pemakaian BB didominasi oleh tipe subjek NAD,NBD, NCD dan NCM yang merupakan kelompok jaba dari ketiga tipe pekerjaan dan didominasi oleh umur tua.

Faktor utama yang menjadi sebab dari pemakaian variasi bahasa yang berbeda tersebut ialah identitas. BA, misalnya, dipakai untuk menunjukkan identitas ke-tri wangsa-an sebagai bentuk hormat terhadap diri sendiri dan orang lain. Hal ini sering dikaitkan dengan ungkapan 'Hormati orang lain kalau ingin dihormati'. Jadi, kalau seorang tri wangsa ingin dihormati dengan pemakaian BA, ia perlu untuk memakai BA terhadap lawan tuturnya.

$\mathrm{BI}$ berasosiasi dengan netralitas (bebas wangsa), nasionalisme dan modernisasi yang merupakan ciri dari kelompok penutur muda, terutama dari pekerjaan (kelas sosial) tinggi dan menengah. Berbeda dengan $\mathrm{BI}$, BB sering diasosiasikan dengan persamaan dan solidaritas yang merupakan ciri dari penutur dari kelompok jaba.

\section{SARAN}

Hasil kajian ini secara sederhana bisa memberikan gambaran mengenai variasi pemakaian bahasa pada masyarakat tutur kota Singaraja dalam kaitannya dengan wangsa, pekerjaan dan umur. Walaupun demikian, penelitian ini terutama 
sekali masih belum menggali data terkait dengan pemakaian BK yang dikenal secara kental mewarnai bahasa pergaulan di kota Singaraja sehingga bisa dikatakan gambaran yang dipaparkan di dalam penelitian ini masih jauh dari sempurna. Untuk menggali data BK model 'status sosial' (Labov, 2006) yang diterapkan pada penelitian ini sepertinya masih belum mampu untuk melakukan hal tersebut. Sehingga, untuk memperoleh gambaran lebih lengkap tentang variasi pemakaian bahasa di kota Singaraja model tersebut perlu untuk dikombinasikan dengan model 'jejaring sosial' yang diperkenalkan oleh Milroy (1992).

\begin{tabular}{|c|c|c|c|}
\hline \multicolumn{4}{|c|}{ DAFTAR SINGKATAN } \\
\hline $\mathrm{BA}$ & Basa Alus & TCD & $\begin{array}{l}\text { Tri wangsa - pekerjaan } \mathrm{C} \text { - umur tua } \\
\text { (dewasa) }\end{array}$ \\
\hline BB & Basa Biasa & TCM & Tri wangsa - pekerjaan $\mathrm{C}$ - muda \\
\hline BK & Basa Kasar & NAD & $\begin{array}{l}\text { Jaba - pekerjaan A - umur tua } \\
\text { (dewasa) }\end{array}$ \\
\hline $\mathrm{BI}$ & Bahasa Indonesia & NAM & Jaba - pekerjaan A - umur muda \\
\hline $\mathrm{BL}$ & Bahasa Lain & NBD & $\begin{array}{l}\text { Jaba - pekerjaan B - umur tua } \\
\text { (dewasa) }\end{array}$ \\
\hline TAD & $\begin{array}{l}\text { Tri wangsa - pekerjaan A - umur } \\
\text { tua (dewasa) }\end{array}$ & NBM & Jaba - pekerjaan B - umur muda \\
\hline TAM & $\begin{array}{l}\text { Tri wangsa - pekerjaan A - umur } \\
\text { muda }\end{array}$ & NCD & $\begin{array}{l}\text { Jaba - pekerjaan C - umur tua } \\
\text { (dewasa) }\end{array}$ \\
\hline TBD & $\begin{array}{l}\text { Tri wangsa - pekerjaan B - umur } \\
\text { tua (dewasa) }\end{array}$ & $\mathrm{NCM}$ & Jaba - pekerjaan C - umur muda \\
\hline TBM & $\begin{array}{l}\text { Tri wangsa - pekerjaan B - umur } \\
\text { muda }\end{array}$ & & \\
\hline
\end{tabular}

\section{DAFTAR PUSTAKA}

Anderson, Edmund A. 1997. "Speech Levels: The Case of Sundanese". Dalam Pragmatics 3 (2): 107-136

Badan Pembina Bahasa, Aksara dan Sastra Propinsi Bali. 2006. Tata Basa Bali. Denpasar: Dinas Kebudayaan Propinsi Bali.

Bagus, I Gusti Ngurah. 1979. Perubahan Pemakaian Bentuk Hormat dalam Masyarakat Bali. (disertasi). Jakarta: Universitas Indonesia.

Bell, Allan. 1984. Language Style as Audience Design. Language in Society, 13: 145-204
Chaer, Abdul dan Agustina Leonie. 2004. Sosiolinguistik: Perkenalan Awal. Jakarta: Penerbit Rineka Cipta

Chambers, J.K. 2003. Sociolinguistic Theory. Oxford: Blackwell Publishing

Fishman, Joshua A. 1972. The Sociology of Language: An Interdisciplinary approach to Language in Society. Massachusetts: Newbury House Publisher.

Gautama, Wayan Budha. 2006. Tata Sukerta Basa Bali. Denpasar: CV Kayumas Agung.

Jendra, Wayan dkk. 1975/1976. Sebuah Deskripsi tentang Latar Belakang Sosial Budaya Bahasa Bali. Denpasar: Pusat Pembinaan dan 
Pengembangan Bahasa, Departemen Pendidikan dan Kebudayaan.

Karepun, Made Kembar. 2007. Mengurai Benang Kusut Kasta: Membedah Kiat Pengajegan Kasta di Bali. Denpasar: PT Empat Warna Komunikasi.

Kersten, J. 1984. Bahasa Bali. Ende-Flores: Penerbit Nusa Indah.

Labov, William. 2006. The Social Stratification of English in New York City. Cambridge: Cambridge University Press

Mesthrie, Rajend; Joan Swann; Ana Deumert dan William L. Leap. 2009. Introducing Sociolinguistics. Edinburgh: Edinburgh University Press

Meyerhoff, Miriam. 2011. Introducing Sociolinguistics. New York: Routledge

Milroy, James. 1992. Linguistic Variation and Change. Oxford: Basil Blackwell Ltd.

Narayana, IB Udara. 1983. Anggah Ungguhing Basa Bali dan Peranannya Sebagai Alat Komunikasi bagi Masyarakat Suku Bali. Denpasar: Universitas Udayana

Purwoko, Herudjati. 2008. Jawa Ngoko: Ekspresi Komunikasi Arus Bawah. Indonesia: PT Macanan Jaya Cemerlang.
Sastrodiwiryo, Soegianto Dr. 2011. Perang Jagaraga (1846-1849). Denpasar: Pustaka Bali Post.

Shadeg, Norbert. 2006. Tuttle BalineseEnglish Dictionary.USA:Tuttle

Publishing.Spolsky, Bernard. 2003. Sociolinguistics. Oxford: Oxford University Press.

Suastra, I Made. 1998. Speech Levels and Social Change: A Sociolinguistic Study in the Urban Balinese Setting. (Dissertation). Australia: La Trobe University

Suryawan, I Ngurah. 2010. Genealogi Kekerasan dan Pergolakan Subaltern: Bara di Bali Utara. Jakarta: Prenada Media Group.

Tim Peneliti Fakultas Sastra Universitas Udayana. 1978/1979. Unda Usuk Bahasa Bali. Laporan Penelitian. Jakarta: Departemen Pendidikan dan Kebudayaan.

Teddlie, Charles dan Abbas Tashakkori. 2009. Foundations of Mixed Methods Research. California: SAGE publication, Inc

Wardhaugh, Ronald. 2006. An Introduction to Sociolingustics. Oxford: Blackwell Publisher Ltd.

Wessing, Robert. 1974. "Language Levels in Sundanese". Dalam Man, New Series 9 (1): 5-22.

Wingarta, Putu Sastra. 2009. Meboya: Kearifan Lokal Buleleng dan Restorasi Nilainya. Yogyakarta: Universitas Gajah Mada. 